\title{
LENITION IN THE MOZARABIC DIALECTS: A REAPPRAISAL
}

DAVID HANLON

Birkbeck College, University of London

\begin{abstract}
Description of the varieties of Romance formerly spoken in al-Andalus is complicated by the documentation of the greater part of the extant textual evidence in an alphabet which had been contrived to represent the sound system and syllabic structure of an unrelated language, and by the lack of any appreciable attempt on the part of the alphabet's users to adapt it to this new task. Lenition provides a measure of the difficulties this poses: whereas it has been possible to speculate on why the intervocalic plosives of Latin voiced in other varieties of HispanoRomance, students of the Mozarabic dialects have sought to establish whether such lenition took place at all. Opinion remains divided between those, like Meyer-Lübke ${ }^{1}$, who believe that it did not occur, and those, like Menéndez Pidal ${ }^{2}$, who believe that it did.
\end{abstract}

Meyer-Lübke affirms that the voicing of the intervocalic plosives in the Peninsula did not take place until after the Germanic invasions ${ }^{3}$. He concludes from an acritical examination of the material that continuations of Latin /-t-/ and /-k-/ remained voiceless in the Mozarabic dialects at the time of the Islamic invasions ${ }^{4}$, a view shared by Hall 5 . Griffin observes that Latin /-t-/ and /-k-/ are transcribed as (voiceless) $t \bar{a}$ ' and $q \bar{a} f$ respectively in the Vocabulista in arabico. He argues that the former was identified with Romance /-t-/, a dental plosive that had lost some its articulatory force but remained voiceless ${ }^{6}$, and that the latter

1 Meyer-Lübke, W., "La sonorización de las sordas intervocálicas latinas en español», Revista de Filología Española 11 (1924), 1-32.

2 Menéndez Pidal, R., Orígenes del español (Madrid: Espasa-Calpe, 1968), 253259.

3 Meyer-Lübke, «La sonorización», 3-5.

4 Meyer-Lübke, "La sonorización", 32.

5 Hall, R., A., "La non-lenizione nella Romània occidentale», Romance Philology 28 (1974-75), 533.

6 Griffin, D., A., Los mozarabismos del «Vocabulista» atribuido a Ramón Martí (Madrid: Offprint from Al-Andalus XXIII-XXV, 1961), 57. 
was identified with Romance /-k-/, preferred to $k \bar{a} f$ which was felt to be too palatal ${ }^{7}$. In further support of his case he cites continuations of Latin /-t-/ and /-k-/ that remained voiceless in Hispanisms of fifteenth and sixteenth century Granadan Arabic (ruta, rucata, xucr, etc.), and likewise toponyms and Mozarabisms of modern Spanish (cornato, borchata, marchito, Játiva, caroca, cernícalo, Júcar, etc.) ${ }^{8}$.

To counter the claims of Meyer-Lübke, Menéndez Pidal adduces evidence that the first documented examples of voicing in the Peninsula are from the south: IMUDAVIT < IMMUTAVIT of the second century AD and LEBRA < LEPRA, IUBENTUDIS < IUVENTUTIS and EGLESIE < ECCLESIA of the seventh century ${ }^{9}$. He observes that from the eighth to the eleventh centuries continuations of Latin /-t-/ and /-k-/ are consistently spelt with $t \bar{a}$, and $q \bar{a} f$, and only occasionally by graphs for voiced phonemes such as $d \bar{a} l$ and gayn. He concludes that voiced and voiceless pronunciations coexisted in al-Andalus, but that the voiceles pronunciation, under the guise of $t \bar{a}$ ' and $q \bar{a} f$, predominated because of Arab linguistic conservatism. To support this assertion, he cites Qurtuba< CORDUBA and Saraqusta $<$ CAESAR AUGUSTA, in which țā' and $q \bar{a} f$ are transcriptions of etymological /d/ and /g/ respectively ${ }^{10}$. Conservatism of this kind, as a result of the prestige of a literary standard, has been and remains a powerful force in Arabic-speaking communities. However, there is no evidence of a strong trend towards voicing in Andalusian Arabic (there are a handful of examples of $/ \mathrm{t} />/ \mathrm{d} /$ in final position, and one in intervocalic position ${ }^{11}$, as well as evidence of $/ \mathrm{t} />/ \mathrm{d} /{ }^{12}$ ), and therefore the voiced pronunciation of intervocalic stops would not have been considered a deviation from any received pronunciation among speakers of Arabic. It is unlikely that Latin is the prestige variety in this instance, since it enjoyed little standing among speakers of Romance (witness the Indiculus luminosus of Alvarus), let alone speakers of Arabic. Galmés de Fuentes overcomes this difficulty without making explicit reference to it. He argues that the eighth-century grammarian Sibawayhi classifies $t \bar{a}$ ' and $q \bar{a} f$ as "voiced consonants» (hurūf majhüra),

7 Griffin, Los mozarabismos, 60.

8 Griffin, Los mozarabismos, 60-61.

9 Menéndez Pidal, Orígenes, 254.

10 Menéndez Pidal, Orígenes, 254-255.

11 Corriente, F., A Grammatical Sketch of the Spanish-Arabic Dialect Bundle (Madrid: Instituto Hispano-Arabe de Cultura, 1977), 37.

12 Corriente, A Grammatical Sketch, 39-40. 
and that they were, therefore, originally graphs for voiced consonants in Arabic ${ }^{13}$. He observes that continuations of Latin /-t-/ and /-k-/ are habitually transcribed as $t \bar{a}$ ' and $q \bar{a} f$, and occasionally as $t \bar{a}$ ' and $k \bar{a} f$ in other positions; therefore they represent voiced dental and velar plosives respectively ${ }^{14}$. According to this view, Qurtuba $<$ CORDUBA and Saraqusta $<$ CAESAR AUGUSTA are no longer examples of hypercorrection. Toponyms and Mozarabisms in later Granadan Arabic and the lexis of modern Spanish that evince no voicing are attributed to a trend towards devoicing in Andalusian Arabic ${ }^{15}$. This is also the view adopted by Peñarroja ${ }^{16}$, but one slightly modified by Hilty in an independent survey of the material ${ }^{17}$. He concludes that at the time of the Islamic invasions, there existed three groups of phonemes resulting from the Latin intervocalic dentals and velars: /-ð-/ $</-\mathrm{d}-/$ (transcribed as $\underline{d a} l$ ) and $/-\mathrm{r}-/</-\mathrm{g}-/$ (transcribed as gayn); $/-\mathrm{d}-/</-\mathrm{t}-/$ (transcribed as $t \bar{a})$ and $/-\mathrm{g}-/</-\mathrm{k}-/$ (transcribed as $q \bar{a} f)$; $|-\mathrm{t}-|</-\mathrm{t}-/$ (transcribed as $t \bar{a}$ ) and $/-\mathrm{k}-/</-\mathrm{ki}-/$ (transcribed as $k \bar{a} f)$. In a further development, continues Hilty, the results of Latin /-d-/ and /-t-/ on the one hand, and Latin /-g-/ and /-k-/ on the other, merged into voiced dental and velar phonemes respectively with alternative plosive and fricative allophones ${ }^{18}$.

The main argument of this paper is not to show that the Mozarabic dialects are characterized either by voicing of Latin /-t-/ and /-k/, or by the retention of a voiceless pronunciation, but to demonstrate that the use of $t \bar{a}$ ' and $q \bar{a} f$ cannot, by itself, be adduced as proof for either possibility, and that previous arguments have assumed, mistakenly, that the Arabic used in al-Andalus was a stable linguistic variety whose sound system may be fixed diachronically and synchronically.

If the Arabic alphabet was used to write down Romance, it must be assumed that it followed the conventions of Arabic and not those of La-

13 Galmés de Fuentes, A., Dialectología mozárabe (Madrid: Gredos, 1983), 61-62.

14 Galmés de Fuentes, Dialectología mozárabe, 92-96.

15 Galmés de Fuentes, Dialectología mozárabe, 92, 177, 202.

16 Peñarroja Torrejón, L., El mozárabe de Valencia (Madrid: Gredos, 1990), 339348.

17 Hilty, G., "Das Schicksal der lateinischen intervokalischen Verschßlaute -p-, -t-, -k- im Mozarabischen", Festschrift Kurt Baldinger zum 60. Geburtstag, eds. Manfred Höfler, Herni Vernay and Lothar Wolf (Tübingen: Niemeyer, 1979) 1, 145-160.

18 Hilty, "Das Schicksal», 158-160. 
tin. Therefore, Galmés de Fuentes is right to seek to discover the phonological value of $t \bar{a}$ ' and $q \bar{a} f$. However, his study limits itself to the literary language but paradoxically appeals to evidence for the spoken language to account for anomalous voiceless Mozarabisms and toponyms that survived the extinction of the Mozarabic dialects. This procedure relies on three assumptions that may be challenged: first, that an eighthcentury Persian grammarian is an authoritative source for the Arabic used for written purposes in al-Andalus; second, that such a written language was widely known in all epochs during which any loans are likely to have been made; and third, that consequently it was the dominating factor when the Arabic alphabet was used to write down vernacular Romance.

To my knowledge, $t \bar{a}$ ' is universally realized in Classical Arabic as a voiceless plosive. However, Sibawayhi, an early and respected authority, appears to prescribe a voiced pronunciation; he states that if were not for the velar contour, ța ' would become däl (lawlä l-ițbäqu la-șärati l-tă 'u dālan) ${ }^{19}$. This is an unequivocal statement; the controversy over whether the distinction mahmüs ("whispered") and majhür ("clearly used»), to which Galmés de Fuentes appeals, corresponds to the voice vs. voiceless distinction made by modern phonology need not detain us ${ }^{20}$. However, Sibawayhi also documents a voiceless pronunciation which he describes as «infrequent and unacceptable» ${ }^{21}$. It appears that despite the prescription of Sibawayhi, the literary standard throughout the Arabic-speaking world favoured the voiceless pronunciation which established itself rapidly ${ }^{22}$. It would seem that al-Andalus was no exception to this norm on the evidence of the censorship of a voiced realization of $t \bar{a}^{\prime}$ in the lahn al-'ámma literature: qubbayd $<$ qubbayt ${ }^{23}$;

19 Quoted from Maṭar, 'A., Laḥn al-'āmma fĩ ḍw' al-dirāsāt al-lugawiyya al-ḥadītha (Cairo: Al-dār al-qawmiyya li-l-țibā'a wa-l-nashr, 1966), 224.

20 See Blanc, H., "The "Sonorous" vs. "Mufled" Distinction in Old Arabic Phonology", To Honour Roman Jakobson (Mouton: The Hague, 1967) I, 295-308; Garbell, I., "Remarks on the Historical Phonology of an Eastern Mediterranean Arabic Dialect", Word 14 (1958), 303-337; al-Nassir, A. A., Sibawayh the Phonologist (London and New York: Kegan Paul International, 1993), 35-38.

21 Al-Nassir, Sibawayh, 19.

22 Cantineau, J., Etudes de linguistique arabe (París: Klincksieck, 1960), 32, 171.

23 Al-Zubaydī, Lahn al-'āmma, ed. 'Abd al-'Azīz Maṭar (Cairo: Dār al-ma'ārif, 1981), 112. 
qubbayd $<$ qubbayt ${ }^{24} ;$ muliddun $<$ mulittun ${ }^{25} ;$ dābid $<$ dābit ${ }^{26}$. In the case of $q \bar{a} f$, the pedagogic tradition, in particular that of Quranic recitation, universally favours the voiceless pronunciation, again despite the prescription of Sibawayhi. Cantineau suggests that this is because of the predominance of the voiceles pronunciation in urban communities where schoolmen were educated ${ }^{27}$. It is difficult to know whether the written Arabic of al-Andalus was characterized in the same way since there is no explicit censure of a voiced pronunciation in the lahn al-'ämma literature. However, grammarians do comment on the confusion of $q \bar{a} f$ and $k \bar{a} f$, which appear to have suffered a phonemic merger, at least partially, since they were distinguished only by a narrow difference in point of articulation ${ }^{28}$ : hakk< huqq ${ }^{29}$; tarka$w a<$ tarquwa $^{30} ;$ maqqās $<$ makkās ${ }^{31} ; q u b<k \bar{u} b^{32} ;$ istaktala $<$ istaqtala ${ }^{33}$; Washka $<$ Washqa ${ }^{34}$. Educated speakers were particularly careful when reciting the Quran to give $q \bar{a} f$ an uvular pronunciation, but would disregard the uvular/velar distinction in speech, on the evidence of the following remark by al-Safadi concerning the grammarian Abū Hayyān (1256-1344): "His pronunciation is correct [in] the speech of al-Andalus, he articulates the qäf close to $k \bar{a} f$, although in [recitation] of the Quran his pronunciation [of $q \bar{a} f$ ] is correct» ${ }^{35}$. This indicates a voiceless pronunciation in the written language and upper registers of the spoken languages.

It would seem that, despite his authority as a codifier of the written language, Sibawayhi's prescriptions regarding the realization of $t \bar{a}$ ' and $q \bar{a} f$ were largely ignored by many educated speakers of Arabic in al-Andalus.

${ }^{24}$ Ibn Hishām al-Lakhmī, Al-madkhal ilà taqwīm al-lisān wa-ta lïm al-bayān, ed. José Pérez Lázaro (Madrid: Consejo Superior de Investigaciones Científicas, 1990) 2, 56.

25 Ibn Hishām, Al-madkhal 2, 190.

26 Ibn Hishām, Al-madkhal 2, 260.

27 Cantineau, Études, 67.

28 Corriente, A Grammatical Sketch, 54; for later periods see Barceló Torres, M. C., Minorías islámicas en el País Valenciano. Historia y dialecto (Valencia: Instituto HispanoArabe de Cultura, 1984), 175.

29 Al-Zubaydī, Lahn al-ämma, 80.

30 Al-Zubaydì, Lahn al-'āmma, 122.

31 Al-Zubaydì, Lahn al-'āmma, 143.

32 Al-Zubaydì, Lahn al-'āmma, 152.

33 Al-Zubaydì, Lahn al-'āmma, 200.

34 Ibn Hishām, Al-madkhal 2, 287.

35 Quoted from al-Ṭayyār, R. 'A., Al-dirāsāt al-lugawiyya fĭ l-Andalus (Baghdad: Dār al-Rashīd li-l-nashr, 1980), 223. 
A good deal of the evidence for the Mozarabic dialects consists of Romance items borrowed by Arabic. Loans of this kind are typically made during a period of cultural clash; the invading language is forced to borrow since it does not have the lexical resources to denote the referents (flora, fauna, etc.) of its new environment. In the context of alAndalus, this period is likely to comprise the three centuries between the invasion of the Peninsula and the political zenith of the Umayyad caliphate. Assuming for a moment that the prescriptions of Sibawayhi are relevant, was the written language, for which he is regarded an authority, well known throughout this period to the extent that it could influence the orthography of Romance borrowings?

During the period immediately following the invasion, written Arabic is unlikely to have been well known. The conquerors of the Peninsula where a mixture of Berbers and Arabs, of which the former appear to have been the larger group. Linguistically little is known about them ${ }^{36}$. Presumably they spoke Berber, but they had recently been subdued by Arabic-speaking forces and converted to Islam. We would assume that as a speech group they were characterized by an incipient Berber/Arabic bilingualism whose exact nature is impossible to ascertain. The Arabs comprised Yemeni tribesmen who entered the Peninsula under the command of Mūsà ${ }^{37}$, and Syrian forces commanded by Balŷ b. Bišr who arrived in 741 under caliphal orders to calm Berber unrest ${ }^{38}$. The vast majority of this Arabic-speaking body of men is unlikely to have known the literary dialect well. It is likely that the speakers who were responsible for borrowing Romance items in this period comprised the invading troops and their immediate descendants, who were possibly a poorly educated and, in some cases, illiterate group. Even if $t \bar{a}$ ' and $q \bar{a} f$ were voiced consonants in written Arabic, speakers would probably have given them the values of their native phonemic systems if they could write. Since the Arabic spoken in the Peninsula during this period was necessarily characterized by imported dialectal divergence, the geographical back-ground of the invaders and early settlers determined its major constituents, that is to say, Yemeni and

36 Wasserstein, D. J., "The Language Situation in al-Andalus», Studies on the Muwaššạ and the Kharja, eds. Richard Hitchcock and Alan Jones (Reading: Ithaca Press, 1991), 4, 12-13.

37 Ṭāhā, 'A. D., The Muslim Conquest and Settlement of North Africa and Spain (London: Routledge, 1989), 94, 118-128.

38 Ṭāhā, The Muslim Conquest, 132. 
Syrian tribesmen and their clients who dominated the political stage of the nascent Andalusian state and whose dialects would have enjoyed widest currency. Orthographic vagaries would have occurred because of this dialectal divergence: a modern example would be English /g/ transcribed as jim in Egypt and $q \bar{a} f$ in the Gulf region. Residual Yemeni features have been detected in Andalusian Arabic ${ }^{39}$. Indeed, Yemeni linguistic features have clearly influenced the orthography of Romance loans in Peninsular Arabic, for example the plosive jïm in Täjuh $<$ TAGUS and Jalliqiyya < GALLAECIA ${ }^{40}$. Another Yemeni feature is the voiced pronunciation of $t \bar{a}^{\prime}{ }^{41}$. Therefore, during this period, for speakers of Arabic in the Peninsula $t \bar{a}$ ' was likely to have been a graph for voiced and voiceless dental stops. The voiced pronunciation of $q \bar{a} f$ is widely distributed among the rural varieties of spoken Arabic: the north of the Arabian Peninsula, the Yemen, Oman, Iraq, Upper Egypt, the Hawrān, Jordan, Algeria, Morocco and southern Tunisia ${ }^{42}$. The voiceless pronunciation is characteristic of the settled urban areas of Syria, Iraq, North Africa, Tunisia, Morocco, Algeria and Oran ${ }^{43}$. Whether the same rural/urban distribution was characteristic of al-Andalus immediately following the Islamic invasions is not known, but it is almost certainly true that both pronunciations existed. Therefore, the written language is unlikely to have influenced the orthography of Romance loans made during this period, and furthermore it is impossible to identify with any degree of accuracy what values $t \bar{a}$ ' and $q \bar{a} f$ may have had.

There are two valuable sources for determining the extent of the knowledge of the written language in al-Andalus from the post-invasionary period to the fourth century AH. The first is the Tärikh 'ulamā', al-Andalus whose author, Ibn al-Faradị, was born in Córdoba in 351/ $962{ }^{44}$. He achieved renown as a jurist and hadī scholar, was appointed $q \bar{a} d \bar{l}$ of the great mosque of Valencia, and died in the Berber sack of

39 Corriente, F., "South Arabian Features in Andalusī Arabic», Studia Linguistica et Orientalia Memoriae Haim Blanc dedicata, eds. Paul Wexler, Alexander Borg and Sasson Somekh (Wiesbaden: Otto Harrassowitz, 1989), 94-103.

40 Corriente, "South Arabian Features», 98.

41 Cantineau, Études, 32.

42 Cantineau, Études, 69-70; al-Nassir, Sibawayhi, 37.

43 Cantineau, Études, 68-69; al-Nasssir, Sibawayhi, 37.

44 Ibn al-Faraḍi, Tārīkh 'ulamā' al-Andalus, ed. Ibrāhīm al-Abyārī, 2 vols. (Cairo and Beirut: Dār al-kutub al-islāmiyya, 1983), henceforth known as IF for the sake of convenience. 
Córdoba led by al-Musta'in in 403/1013 ${ }^{45}$. The work is among the older and more complete of the Andalusian biographical dictionaries ${ }^{46}$, whose chronological scope ranges from the date of the invasion to the end of the fourth century AH. The second is the Tabaqāt al-nahwiyyin wa-l-lugawiyyin, whose author, Abū Bakr al-Zubaydī, was born in Seville in 316/982 ${ }^{47}$. He studied in Córdoba under Abū 'Alī l-Qālī and became judge of the great mosque and șăhib al-shurța in Seville, where he died in 379/989 ${ }^{48}$. The chronological scope of the Tabaqāt ranges from Abū l-Aswad al-Du'alī (d. 69/688), to al-Zubaydī's teacher Muhammad b. Yahyà al-Rabāhī (d. 358/968). The two sources yield sufficient data to construct a sample of one hundred and fifty-one individuals said to be grammarians or interested in grammar and lexicography who lived during the period circumscribed by the Islamic invasions and the zenith of the Umayyad Caliphate. The sources mention a further thirty-nine individuals whose date of birth/and or death are not given either independently of or relative to contemporary political events. I have omitted twenty-nine from the final sample but have included ten by supplementing the data of the sources with extensive biographical research carried out by Marín ${ }^{49}$; it should be noted, however, that the quality of the sample has been compromised which qualifies the conclusions reached in this study

45 Pons Poigues, F., Ensayo bio-bibliográfico sobre los historiadores y geógrafos arábigo-españoles (Madrid: Establecimiento Tipográfico de San Francisco de Sales, 1898), 105-108.

46 Ávila, M. L. and Marín, M., "Le Ta'rīh 'Ulamā' al-Andalus d’Ibn al-Faradīi: étude et informatisation", Cahiers d'Onomastique Arabe 1985-87, (París: Editions du Centre National de la Recherche Scientifique, 1989), 41-42.

47 Al-Zubaydī, Tabaqät al-nahwiyyīn wa-l-lugawiyyīn, ed. Muhammad Abū l-Faḍl Ibrāhīm (Cairo: Muhammad Sāmī Amīn al-Khanji, 1954), henceforth know as AZ for the sake of convenience.

48 IF no. 1355, pp. 786-789; Pons Boigues, Ensayo, 90-93.

49 Marín, M., "Nómina de sabios de al-Andalus (93-350/711-961)", Estudios onomástico-biográficos de al-Andalus I, ed. M. Marín (Madrid: Consejo Superior de Investigaciones Científicas, 1988), 23-182. The twenty-nine scholars omitted are (note that in cases where I am unsure of the proper vocalization of names, I have ommitted the short vowels): Ibrāhīm b. Wahb (IF no. 44, p. 52); Bakr b. Khatib al-Murādī 1-Makfūf al-Nahwīi (IF no. 290, p. 174; AZ, p. 297); Sulaymān b. Yūsuf al-Qaysī (IF no. 562, p. 329); Șā‘id al-Muqri’ (IF no. 612, p. 356); Diyā' b. Abī 1-Daw' (IF no. 616, p. 357; AZ, p. 317); 'Abd al-Raḥmān b. Hassān al-Khawlānī (IF no. 792, p. 447); 'Uthmān b. Shann (IF no. 893, p. 515); Abū l-Fath Sa'dà (AZ, p. 308); Aḥmad b. 'Abd al-Karīm (AZ, p. 313); Muhammad b. Așbag b. Nāṣị al-Murādī l-Mujaddir (Az, p. 313); Abū 1-'Abbās Bajwam (AZ, p. 314); Ibn Waqqāṣ al-Qurašī (AZ, p. 315); Mudhaj al-Mu'addib (AZ, p. 315); Muḥammad b. Ganim al-Udaynī (AZ, p. 315); 'Abd 
(the blame for this lack of detail is usually to be laid at the door of alZubaydi whose standards of scholarship fall short of those set by Ibn al-Faraḍi).

Towards the end of the first century of Islamic administration, and the beginning of the second, we see the first signs of an attempt to establish Arabo-Islamic cultural supremacy, and to foster a knowledge of the literary koine of the Islamic world. Only two scholars are mentioned who are reputed to have known the literary dialect well: the Cordoban al-Gāzī b. Qays (d. 199/814), who was a student of Mālik b. Anas and also met al-Așma'ī and other linguists (IF no. 1013, p. 578; AZ, pp. 276-278); and Jūdī b. 'Uthmān (d. 198/813) from Morón, but who later settled in Córdoba. He met al-Kisā'î, al-Farrā' and others, was said to have introduced a work by al-Kisā'ī to al-Andalus (wa-huwa awwalu man adkhala kitäba l-Kisā '̄), and to have written a work on grammar (AZ, pp. 278-279).

Towards the end of the second century $\mathrm{AH}$ and throughout the third, a knowledge of written Arabic spread further through the population. Thirty-one scholars are mentioned by Ibn al-Faradī and al-Zubaydì who achieved fame for their knowledge of the written standard and who died in the third century AH. Although the majority (seventeen) are from Córdoba, there is evidence of a wider geographical spread of expertise, with scholars from Saragossa, Jaén, Carmona, Niebla, Elvira, Ecija, Tākurunna, Morón and Algeciras. There are several figures of importance. The polymath and author of a universal history (Kitāb altārîkh), 'Abd al-Malik b. Habỉb (d. 238/853), was also considered a grammarian by his contemporaries (IF no. 814, p. 459; AZ, pp. 282283) ${ }^{50}$. 'Uthmān b. al-Muthannà (d. 273/886) from Córdoba travelled to the East, met various scholars of grammar and studied under Abū Tammām whose dīwān he brought to al-Andalus (IF no. 889, p.

Allāh b. Mu'min b. 'Udāfir al-Tûîibī 1-Marwakī (AZ, p. 316); 'Īsā b. Abī Jurthūmat al-Khawlānī (AZ, p. 316); Bahlūl al-Ja'thamī (AZ, p. 317); Țāhir (AZ, p. 317); 'Abd al-Șamad (AZ, p. 317); 'Uthmān b. 'Amr al-Mawrūrī (AZ, p. 318); Yūsuf b. Sulaymān al-Kātib (AZ, p. 322); Abū 'Abd Allāh al-Mklfkhī (AZ, p. 329); Aḥmad b. Maḍā' Ibn al-Hișār (AZ, p. 331); Idrīs b. Mytm (AZ, p. 332); Faraj b. Fzlmān (AZ, p. 334); 'Uthmān b. Ibrāhīm al-Brshqīīi (AZ, p. 334); Isḥāq b. Ibrāhīm b. Muḥammad (AZ, p. 334); 'Āfĩ b. Sa'īd al-Makfüf (AZ, p. 334); Muhammad b. Fath (IF no. 1296, p. 738).

50 See also Pons Boigues, Ensayo, 29-38; Aguadé, J. in Ibn Habỉ, 'Abd al-Malik, Kitāb al-ta'rïj, ed. Jorge Aguadé (Madrid: 1991), 15-56. 
513; AZ, p. 288) ${ }^{51}$. The Cordoban traditionist Muhammad b. 'Abd al-Sallām al-Khushanì (d. 286/899) travelled to the East where he met grammarians of the school of al-Așma'i , and introduced works of grammar to al-Andalus (IF no. 1132, p. 648; AZ, p. 290) ${ }^{52}$. 'Abd alRahimān b. Mūsà from Ecija travelled to the East and studied under Mālik b. Anas and al-Aṣma'ī (IF no. 776, p. 439; AZ, pp. 275-276). 'Abd al-Wāhid b. Sallām (d. 209/824), was a famed teacher of grammar and author of a work on grammar (IF no. 856, p. 494; AZ, p. 279). 'Abbās b. Firnās (d. 274/887), a polymath and inventor who pioneered the production of rock crystal and made a half-successful attempt at flight ${ }^{53}$, was also famed for his knowledge of the literary standard (AZ, pp. 291-292) ${ }^{54}$. 'Abbās b. Nāșih al-Thaqafi of Algeciras, famed for his panegyrics of al-Hakam b. Hishām (180/796-206/ $822)$, travelled to the East with his father and met Abū Nuwās and alAșma'i (IF no. 879, pp. 504-505; AZ, p. 284). Other authors of works on grammar include Mufarrij b. Mālik al-Nahwī from Córdoba (IF no. 1446, p. 843; AZ, p. 297), and Yahyà b. 'Abd al-Raḥmān (d. 263/876) of Saragossa (IF no. 1559, p. 902).

In this as in other periods of Andalusian history, state intervention in education was non-existent ${ }^{55}$. For this reason, mosques assumed importance as centres of education; they did duty as public libraries and were the only exposure to learning and the literary standard for those who wished to better themselves but did not have the means to provide for private tuition. Scholars and clerics would establish a circle ( halqa) and give lectures on matters religious, linguistic and literary. For the common believer, mosques brought familiarity with the received pronunciation used in common prayer and liturgy. In the major provincial centres great mosques were founded throughout the ninth century: Seville (214/829); Jaén (218/833); and Lérida (289/901).

Sponsorship of the literary standard reached its fruition in the reign of 'Abd al-Rahmān III (300/912-350/961), which saw the political unification and apogee of the Andalusan state. The indigenous popula-

${ }^{51}$ See also Ibn Sa‘īd al-Magribī, Al-mugrib fi hulà l-magrib, ed. Shawqī Ḍayf (Cairo: Dār al-ma‘ārif, 1953) 1, 112.

52 See also Pons Boigues, Ensayo, 48.

53 Ibn Sa'īd, Al-mugrib 1, 333; Vernet, Juan, La cultura hispanoárabe en Oriente y Occidente (Barcelona: Ariel, 1978), 28.

54 Date of death given in Ibn Sa'îd, Al-mugrib 1, 333.

55 Ribera y Tarragó, J., La enseñanza entre los musulmanes españoles (Córdoba: Publicaciones de la Real Academia de Córdoba, 1925), 15-25. 
tion began to participate in Arabic and Islamic culture in large numbers; they assumed administrative posts and conversion became commonplace. Accordingly, the figures given by Ibn al-Faradī and al-Zubaydī increase dramatically. There are one hundred and twenty-eight scholars in total reputed to know written Arabic well who died in the fourth century AH. Again, nearly half are from Córdoba (fifty-eight), but the geographical distribution is much greater with representatives from Beja, Seville, Sidonia, Elvira, Ecija, Jaén, Saragossa, Fạ̣s al-Ballūt, Carmona, Algeciras, Osuna, Tortosa, Badajoz, Morón, Calatayud, Toledo, Pechina, Guadalajara and Malaga. This period witnessed one of the most important events in the history of grammatical studies in alAndalus: the arrival of Abū 'Alī Ismā'îl b. al-Qāsim al-Qālī (288/900$356 / 966$ ) from Baghdad in 330/941 to dictate his al-Amälì (IF no. 221 , p. 138) ${ }^{56}$. He exerted considerable influence because of his teaching activities. Those who studied under him include al-Zubaydī himself (IF no. 1355, p. 768), Ibrāhīm b. 'Abd al-Raḥmān al-Tanasī (d. 387/997) of Córdoba (IF no. 47, p. 53), 'Abd Allāh b. Aṣbag (d. 373/ 983) of Córdoba (IF no. 726, p. 407), 'Abd Allāh b. Shu'ayb b. Abī Shu'ayb (d. 389/998) of Osuna (IF no. 753, p. 421), Muhammad b. Ibrāhīm b. 'Abd al-Raḥmān b. Mu'āwiya b. al-Mundir (d. 373/983) of Córdoba (IF no. 1340, p. 761), Muhammad b. Aflah (d. 385/995) of Pechina (IF no. 1369, p. 781), and Hishām b. Hubaysh of Toledo (IF no. 1540, p. 891). Another outstanding figure is Ibn al-Qūtiyya (d. 367/ 977), remembered to posterity principally for his historical writings, but who was also famous to contemporaries as a grammarian and author of such works as Kitāb tașārîf al-af'āl and Kitāb al-maqșūr wa-lmamdüd (IF no. 1316, p. 747). Makkī has documented the spectacular rise in the importation of eastern grammatical and lexicographical works in this period, which further stimulated the cultivation of homegrown scholarship ${ }^{57}$. It is unsurprising, therefore, to note that many scholars from the sample are reported to have made trips to learn directly from scholars in the heartlands of Islam. A number of Andalu-

${ }^{56}$ See Rashīd, B. Y., "Abū 'Alī al-Qālīi: Vida y obra. Estudio de sus transmisiones lingüístico-literarias", Miscelánea de Estudios Arabes y Hebraicos XXXI (1982), 17-45; XXXII (1983-1984), 37-54; XXXIV-XXXV (1985-1986), 271-286; XXXVII (1988), 211-225.

57 Makkī, M. 'A., Ensayo sobre las aportaciones orientales en la España musulmana (Madrid: Instituto Egipcio de Estudios Islámicos, 1968), 256-268. 
sians studied under the Egyptian Abū Ja'far Ahmmad b. Muhammad b. Ismāîl al-Naḥhās (d. 338/950), for example: Khaț̣āb b. Maslama (d. 372/982) of Carmona (IF no. 402, pp. 243-244); 'Abd al-Salām b. alSamh of Morón (IF no. 855, p. 492); Muḥammad b. Isḥāq b. Mundir (d. 367/977) of Córdoba (IF no. 1317, p. 749); Husayn b. Fath of Seville (IF no. 352, p. 207); and Muhammad b. Mufarrij b. 'Abd Allāh (d. 371/ 981) of Córdoba, who is reported to be the first individual to bring to al-Andalus the Kitāb i'rāb al-Qur'ān, Kitäb ma'ānì l-Qur'ān and Kitāb alnāsikh wa-l-mansūkh of al-Naḥhās (IF no. 1329, p. 756). Two further students of Abū Ja'far al-Naḥhās also studied under the Egyptian scholar Ibn Wallād (d. 332/943): Muḥammad b. Yahyyà b. 'Abd al-Salām alRabāhī (d. 358/968), who imported a copy of Sỉbawayhi's Kitāb into the Peninsula (IF no. 1290, p. 736; AZ, p. 336); and Mundir b. Sa'ìd (d. 355/965) of Córdoba (IF no. 1452, p. 845; AZ, pp. 319-320). One Mūsa b. Așbag al-Murādī of Córdoba also studied under the Basran scholar Ibn Durayd (d. 321/933) (IF no. 1462, p. 853). Lastly, Qāsim b. Thābit b. Hazm (d. 302/914) of Saragossa travelled to the East with his father and brought to the Peninsula a copy of the Kitäb al-'ayn (IF no. 1060, pp. 605-606; AZ, p. 309).

In sum, the knowledge of written Arabic was limited to a small élite towards the end of the first century of Islamic administration. It was not to become widespread until the end of the ninth and beginning of the tenth centuries when it was possible for it to exert a levelling influence on the spoken languages and the orthography of borrowings from Romance. For long periods, therefore, it remains impossible to predict the phonological values of $t \bar{a}$ ' and $q \bar{a} f$ when used to write down vernacular Romance. In later periods, it is possible that the prestige of the written language, on the evidence of the lahn al-'amma literature, favoured voiceless pronunciations that were inevitably used in upper registers of the spoken language. It is doubtful, however, whether the lower registers of the spoken language can be ignored, which brings me to my third point.

Was the written language the dominating influence when the Arabic alphabet was used to write down vernacular Romance? The dichotomy established between $\mathrm{H}$ (igh) and $\mathrm{L}$ (ow) varieties of Arabic by Ferguson ${ }^{58}$ has been questioned by Kaye ${ }^{59}$. A linguist who has spent any

58 Ferguson, Ch. A., "Diglossia», Word 15 (1959), 325-340.

59 Kaye, Alan S., "Remarks on Diglossia in Arabic: Well-defined vs. Ill-defined", Linguistics 18 (1972), 32-48. 
length of time in an Arabic-speaking country cannot have failed to notice the myriad gradations that exist along the social and stylistic axes of Arabic, which depend on the education, background and sex of the speaker, as well as the topic of conversation and the interlocuter. Any decision as to where $\mathrm{H}$ begins and $\mathrm{L}$ ends will inevitably seem arbitrary; this would suggest a continuum rather than a discrete $\mathrm{H} / \mathrm{L}$ distinction ${ }^{60}$. For example, in Egypt thä' may be realized as $/ \theta /, / \mathrm{s} /$ or $/ \mathrm{t} /$. Therefore, we must take into acount the values of $t \bar{a}$ ' and $q \bar{a} f$ in lower registers of Arabic.

An urban spoken standard seems to have emerged in the tenth century, the result of the merger of the native dialecte of the early settlers, the influence of the Romance substrate, and the levelling influence of the written superstrate ${ }^{61}$. In this and subsequent periods, $t \bar{a}$ ' had two possible realizations: voiceless and voiced. The former was the prestige norm and the latter suppressed as substandard ${ }^{62}$. The real reason for this may be particular to the language attitudes of al-Andalus (and, therefore, beyond our discovery), but one obvious possibility is that the realization of $t \bar{a}$ ' in written Arabic was voiceless. In the ninth and tenth centuries, $q \bar{a} f$ was consistently unvoiced and merged in many areas with /-k-/, but a voiced pronunciation remained which was substandard and possibly rural ${ }^{63}$. Since before this period spoken Arabic was characterized by a dialectal divergence that has already been commented on, at no time from the invasion to the establishment of the caliphate can $q \bar{a} f$ and $t \bar{a}$ ' in spoken Arabic be identified with fixed phonological values.

Throughout the entire period under review, the phonological values of $t \bar{a}$ ' and $q \bar{a} f$ when used to transcribe reflexes of Latin /-t-/ and /-k-/ cannot be predicted, for different reasons over different periods of time: from the invasion to the eighth/ninth centuries because of the existence of imported dialectal divergence, and the negligible to uneven regulating influence of a literary superstrate; and from the eighth/ninth centuries onwards because, despite the existence of a widely-known li-

${ }^{60}$ Cf. Blanc, H., "Style Variations in Spoken Arabic: A Sample of Interdialectal Educated Conversation", Contributions to Arabic Linguistics, ed. Charles A. Ferguson (Cambridge, Massachusetts: Harvard Middle Eastern Monograph Series, 1960), 81156; El-Hassan, S. A., "Educated Spoken Arabic in Egypt and the Levant: A Critical Review of Diglossia and Related Concepts", Archivum Linguisticum 8, no. 1 (1977), 112 132.

61 Corriente, A Grammatical Sketch, 7.

62 Corriente, A Grammatical Sketch, 39-40.

63 Corriente, A Grammatical Sketch, 53-54. 
terary superstrate, voiced and voiceless realizations of these sounds coexisted in the spoken language, and the social and stylistic variables that determined the use of one rather than the other are possibly beyond our investigation. Corriente may be right that the voiced realizations characterized those communities who prided themselves on their Romance heritage or were stigmatized because of it ${ }^{64}$. But the assertion, on the one hand by an Arabist, that $t \bar{a}$ 'was voiced because it was a graph for Romance /d/ continuing Latin /-t-/ ${ }^{65}$, coupled with the assertion, on the other hand by a Romance scholar, that Latin /-t-/ voiced because $t \bar{a}$ 'was voiced in Arabic ${ }^{66}$, produces a circular argument.

The problem is compounded by the commonly-held assumption that the Mozarabic dialects are a single linguistic variety. Given the linguistic diversity that existed in the area north of the Andalusian border, which for most of the period under review existed within narrower geographical confines, we are probably dealing with several typologically distinguishable linguistic varieties at least as diverse as those to the north (the adoption of a working hypothesis of diversity has been the great contribution to this field of study by Galmés de Fuentes). If this is the case, and given the evidence of voicing of /-t-/ and /-k-/ in non-liturgical Latin texts written in al-Andalus in the ninth and tenth centuries ${ }^{67}$, it is very likely that one or more of the Mozarabic dialects were characterized by voicing of /-t-/ and /-k-/. The task facing those who wish to identify successfully such examples of lenition is to adopt a structuralist approach similar to that used by Hilty ${ }^{68}$, and match reflexes of /-t-/ and /-k-/ transcribed by $t \bar{a}$ ' and $q \bar{a} f$ with examples of frication or deletion of /-d-/ and/or degemination of /-t:-/ from the same time and place. Because their phonological values cannot be predicted, the use of the graphs $t \bar{a}$ ' and $q \bar{a} f$ is not sufficient evidence of such lenition ${ }^{69}$.

${ }^{64}$ Corriente, A Grammatical Sketch, 40.

65 Corriente, A Grammatical Sketch, 40.

${ }_{66}$ Galmés de Fuentes, Dialectología mozárabe, 61-62 et passim.

67 For example, didissimas $<$ DITISSIMAS, repedat $<$ REPETAT, Hludouicus $<$ Germanic Hlutowigch, instripidu < INSTRIPITU, eglesia < ECCLESIA, Gregi < GRECI, diguntur < DICUNTUR in Vespertino Rodríguez, A., «La sonorización de las consonantes sordas intervocálicas en el latín de los mozárabes», Homenaje a Alvaro Galmés de Fuentes (Madrid: Gredos, 1985) 1, 348-349.

${ }^{68}$ Hilty, «Das Schicksal».

${ }^{69}$ I wish to record my gratitude to my colleague Professor Roger Walker, and Dr Richard Hitchcock and Dr Lynn Williams of the University of Exeter, who generously gave their time and expertise to comment on earlier drafts of this paper. 


\title{
RESUMEN
}

El propósito de este estudio no es defender ni negar la sonorización de las /-t-/ y /-k-/ latinas en los dialectos mozárabes, sino proponer que, siendo difícil fijar el valor fonológico de las grafías $t \bar{a}$ 'y $q \bar{a} f$ en los varios registros del árabe andalusí, su uso no prueba la sonorización de dichas consonantes ni su conservación como sordas.

\begin{abstract}
The main argument of this paper is not to show that the Mozarabic dialects were characterized either by voicing of Latin /-t-/ and /-k-/, or by the retention of a voiceless pronunciation, but to demonstrate that, because their phonological values in the various registers of Andalusian Arabic cannot be fixed, the use of $t \bar{a}$ 'and $q \bar{a} f$ cannot be adduced as proof for either possibility.
\end{abstract}

